\title{
ANALISIS PERILAKU PENUMPANG KRL BOGOR - JAKARTA KOTA PADA MASA PANDEMI DAN PENGARUHNYA TERHADAP POLA PERJALANAN
}

\author{
Yohanes William Lois ${ }^{1}$, Dewi Linggasari², dan Hokbyan Angkat ${ }^{3}$ \\ ${ }^{1}$ Program Studi Sarjana Teknik Sipil, Universitas Tarumanagara, Jl. Letjen S. Parman No.1 Jakarta \\ yohanes.325160036@stu.untar.ac.id \\ ${ }^{2}$ Program Studi Sarjana Teknik Sipil, Universitas Tarumanagara, Jl. Letjen S. Parman No.1 Jakarta \\ dewil@ft.untar.ac.id \\ ${ }^{3}$ Program Studi Sarjana Teknik Sipil, Universitas Tarumanagara, Jl. Letjen S. Parman No.1 Jakarta \\ hokbyanr@dtt.untar.ac.id
}

\begin{abstract}
Transportation is a primary need that cannot be separated from life to continue their daily activities, especially nowadays which require a trip bya transportation. Transportation has many options, one of the primadonna for trips in the city of Jabodetabek is the KRL Commuter Line, provided by PT. Kereta Commuter Indonesia. However, currently the Covid-19 pandemic has an impact on transportation trips, including the KRL Commuter Line. Since then, policies regulated by the government have been implemented to stop the spread of Covid-19, such as limiting the number of passengers and enforcing health protocols for passengers and officers. The existence of these restrictions has an effect on transportation travel. This research was conducted to determine the level of awareness of KRL passengers behavior toward the health protocols applied when carrying out activites outside the home and the effect on their travel patterns, as wel as to find out the policies realized by KRL operator officers. The research data were obtained through a questionnaire, then processed by normative anda descriptive analysis methods. From the analysis, it was found that both passengers and officers were quite alert and good at implementing existing policies and passengers revealed that this policy affects their travel patterns.
\end{abstract}

Keywords: KRL Commuter Line; Covid-19 Pandemic; Policy; Health Protocol; Travel Pattern.

\begin{abstract}
ABSTRAK
Transportasi merupakan kebutuhan primer yang tidak dapat dipisahkan dari kehidupan untuk menyambung kegiatannya sehari-hari khususnya pada masa sekarang yang memerlukan suatu perjalanan dengan transportasi. Transportasi punya banyak pilihan, yang menjadi salah satu primadona perjalanan dalam kota Jabodetabek adalah KRL Commuter Line, yang disediakan oleh PT. Kereta Commuter Indonesia. Namun, saat ini adanya wabah pandemi Covid-19 memberikan dampak dalam perjalanan transportasi tidak terkecuali pada KRL Commuter Line. Semenjak itu diterapkanlah kebijakan-kebijakan yang diatur pemerintah guna memutus penyebaran Covid-19, seperti pembatasan jumlah penumpang dan pemberlakuan protokol kesehatan untuk penumpang maupun petugas. Adanya batasan-batasan ini menyebabkan pengaruh pada perjalanan transportasi. Penelitian ini dilakukan untuk mengetahui tingkat kesadaran perilaku penumpang KRL terhadap protokol kesehatan yang diterapkan ketika melakukan kegiatan di luar rumah dan pengaruh terhadap pola perjalanannya, juga untuk mengetahui kebijakan yang direalisasikan oleh petugas operator KRL. Data penelitian didapat melalui kuesioner, lalu diolah dengan metode analisis normatif dan deskriptif. Dari hasil analisis, didapatkan baik penumpang maupun petugas sudah cukup awas dan baik dalam menerapkan kebijakan yang ada dan penumpang mengungkapkan dengan adanya kebijakan ini mempengaruhi pola perjalanannya.
\end{abstract}

Kata Kunci: KRL Commuter Line; Pandemi Covid-19; Kebijakan; Protokol Kesehatan; Pola Perjalanan. 


\section{PENDAHULUAN}

Pada era globalisasi ini sangat banyak hal yang mengalami modernisasi, salah satunya ialah sarana transportasi. Sarana transportasi memiliki peranan yang penting dan tidak dapat dipisahkan bagi kehidupan masyarakat. Semakin banyaknya pilihan jasa transportasi, membuat masyarakat mencari-cari pilihan mana yang paling ideal untuk dirinya sendiri. Contoh yang menjadi pilihan banyak masyarakat ialah Kereta Rel Listrik (KRL).

PT. Kereta Api Indonesia yang merupakan induk perusahaan yang menghadirkan sistem KRL Commuter Line dengan menjadikan PT. Kereta Commuter Indonesia sebagai pengurusnya. Yang menjadi keunggulan pada layanan ini adalah mampu menjangkau lebih banyak stasiun antar daerah dan memiliki jam keberangkatan yang lebih banyak lagi dengan minimal keberangkatan tiap 10 menit sekali, harganya pun juga terjangkau.

Namun, pada 2 Maret 2020 ini Indonesia dikejutkan dengan kasus terkonfirmasi positif virus Covid-19 yang sudah mewabah di seluruh dunia. Terhitung sampai dengan tanggal 29 Mei 2020, Pemerintah Indonesia menyatakan keadaan darurat bencana akibat dari penyebaran virus ini yang terus meningkat dan menyebabkan penetapan kebijakan untuk melakukan tindakan Pembatasan Sosial Berskala Besar dengan sosialisasi gerakan Social Distancing.

Kebijakan pembatasan ini pun berpengaruh pada banyak aspek penting tak terkecuali pada transportasi. Pembatasan ini berlaku di semua moda transportasi, baik itu di darat, laut, maupun udara di era yang bisa kita sebut New Normal ini khususnya pada transportasi umum termasuk pelayanan KRL Commuter Line.

Batasan masalah dalam penelitian ini antara lain:

1. Perilaku dari penumpang yang menggunakan transportasi umum Kereta Rel Listrik (KRL) Commuter Line.

2. Persepsi masyarakat terhadap regulasi dan pola pelayanan dari Kereta Rel Listrik (KRL) Commuter Line berdasarkan protokol kesehatan Covid-19.

Rumusan masalah yang akan dibahas pada penelitian ini adalah:

1. Bagaimana regulasi-regulasi yang berlaku dalam mengatur moda transportasi khususnya kereta Commuter Line pada pemberlakuan Pembatasan Sosial Berskala Besar dalam masa pandemi ini?

2. Bagaimana timbal balik yang dilakukan PT. Kereta Commuter Indonesia selaku operator dalam menerapkan regulasi-regulasi yang berlaku untuk petugas maupun penumpang kereta Commuter Line?

3. Bagaiman persepsi dari masyarakat selaku penumpang dalam menggunakan moda transportasi kereta Commuter Line mengenai regulasi-regulasi yang diberlakukan dalam stasiun maupun kereta?

4. Apakah kebijakan - kebijakan Pembatasan Sosial Berskala Besar yang berlaku pada masa pandemi wabah virus Covid-19 dalam kereta Commuter Line berpengaruh terhadap perjalanan transportasi yang dilakukan masyarakat?

Tujuan dari penelitian ini adalah:

1. Mengetahui apa saja regulasi-regulasi yang berlaku dalam mengatur moda transportasi khususnya kereta Commuter Line pada pemberlakuan Pembatasan Sosial Berskala Besar dalam masa pandemi ini.

2. Mengetahui respon timbal balik yang dilakukan PT. Kereta Commuter Indonesia selaku operator dalam menerapkan regulasi-regulasi yang berlaku untuk petugas maupun penumpang kereta Commuter Line.

3. Mengidentifikasi mengenai persepsi dari masyarakat selaku penumpang dalam menggunakan moda transportasi kereta Commuter Line mengenai regulasi-regulasi yang diberlakukan dalam stasiun maupun kereta.

4. Mengetahui apakah kebijakan Pembatasan Sosial Berskala Besar yang berlaku pada masa pandemi wabah virus Covid-19 dalam kereta Commuter Line berpengaruh terhadap perjalanan transportasi yang dilakukan masyarakat.

\section{Transportasi}

Suatu proses pergerakan atau suatu perpindahan orang atau pun barang dari suatu tempat ke tempat lainnya dengan mempergunakan suatu sistem tertentu dengan maksud dan tujuan tertentu bagi tiap masing-masing pribadi, ialah definisi singkat dari transportasi. Kegiatan yang dilakukan oleh manusia dalam melakukan pemenuhan kebutuhannya menyebabkan mereka perlu untuk melakukan pergerakan (perjalanan transportasi) dan saling berhubungan. Parameter tujuan perjalanan yang sangat berpengaruh di dalam produksi perjalanan (Levinson), adalah tempat bekerja, kawasan perbelanjaan, kawasan pendidikan, kawasan usaha (bisnis), dan kawasan hiburan (rekreasi).

\section{PT. Kereta Commuter Indonesia}

PT. Kereta Commuter Indonesia adalah salah satu anak perusahaan dari PT. Kereta Api Indonesia yang merupakan perseroan dan resmi pada tanggal 15 September 2008. Tugas pokok PT. KCI ialah menyelenggarakan pengusahaan 
pelayanan jasa angkutan kereta api komuter yang berkualitas dan menjadi bagian dari solusi masalah transportasi perkotaan yang semakin kompleks khususnya pada wilayah Jakarta, Bogor, Depok, Tangerang, dan Bekasi.

\section{Pandemi wabah virus corona (COVID-19) di Indonesia}

Di Indonesia sendiri terdeteksi kasus pertama kali pada tanggal 2 Maret 2020, terdapat 2 orang positif terpapar virus covid-19. Dua warga yang terpapar ini dikabarkan terinfeksi virus corona akibat penularan dari WNA Jepang yang saat itu juga terjangkit virus ini.

Data tercatat melalui WHO sampai dengan tanggal 31 Agustus 2020 jumlah kasus positif terinfeksi virus corona mencapai 25.155 .932 orang dan jumlah korban meninggal dunia di seluruh dunia mencapai 844.643 orang. Di Indonesia sendiri sampai pada 12 Oktober 2020 terdapat 336.716 kasus terkonfirmasi dengan jumlah korban meninggal mencapai 11.935 jiwa.

Cepatnya penyebaran virus ini di Indonesia menyebabkan pemerintah membuat kebijakan-kebijakan yang berguna untuk memutus mata rantai wabah ini. Namun menurut Juru Bicara pemerintah untuk penanganan covid-19, Achamd Yurianto karena banyak warga yang tak mengikuti imbauan yang digaungkan pemerintah menyebabkan penyebaran malah semakin cepat. Pemerintah pun memutuskan untuk memperketat kebijakan-kebijakan yang berlaku.

\section{Kebijakan yang diberlakukan Menhub dan PT. KCI}

Gugus Tugas sebagai badan yang menangani soal kebijakan yang berlaku pada masa pandemi ini menerbitkan SE Gugus Tugas No.7 Tahun 2020 setelah masa berlaku SE Gugus Tugas No. 4 Tahun 2020 habus. SE Gugus Tugas No. 7 Tahun 2020 berisi tentang Kriteria dan Persyaratan Perjalanan Orang dalam Masa Adaptasi Kebiasaan Baru Menuju Masyarakat Produktif dan Aman Corona Virus Disease 2019 (Covid-19) yang merupakan salah satu bentuk dari arah kebijakan menuju era new normal demi membangkitkan atau memulihkan roda perekonomian negeri. Di saat yang bersamaan diterbitkan Permenhub No. 41 Tahun 2020 tentang Perubahan atas Peraturan Menteri Perhubungan No. 18 Tahun 2020 tentang Pengendalian Transportasi dalam Rangka Pencegahan Penyebaran Corona Virus Disease 2019 (Covid-19), yang seluruhnya secara garis besar memberikan pelonggaran kapasitas angkutan terhadap masing-masing angkutan.

Masyarakat yang ingin menggnakan KRL Commuter Line diwajibkan untuk memenuhi beberapa persyaratan yang perlu untuk diterapkan. Beberapa di antaranya ialah dengan memenuhi aturan utama dari protokol kesehatan yaitu memakai masker, mencuci tangan, dan menjaga jarak, sangat disarankan untuk menggunakan face shield, pakaian lengan panjang atau jaket. PT. KCI dalam hal ini memfasilitasi tempat cuci tangan beserta sabunnya untuk mencuci, disediakan juga hand sanitizer. Pihak petugas juga berkewajiban melengkapi protokol kesehatan sebagai frontliner yang bertugas, melakukan pengcekan suhu tubuh kepada penumpang yang akan masuk ke area stasiun, pemberlakuan maksimal kapasitas pada tiap pemberangkatannya, bagi lansia $>60$ tahun hanya boleh menaiki rangkaian dari pukul 10.00-14.00 WIB, untuk balita dibawah 5 tahun dilarang naik KRL, di dalam rangkaian kereta dilarang untuk berbicara atau menelfon, memberikan marka-marka untuk menjaga jarak, dan membersihkan rangkaian kereta saat mengakhiri perjalanan.

\section{METODE PENELITIAN}

\section{Diagram alir penelitian}

Alur atau tahapan dari penelitian ini tertera dalam bentuk diagram pada gambar 1 sebagai berikut. 


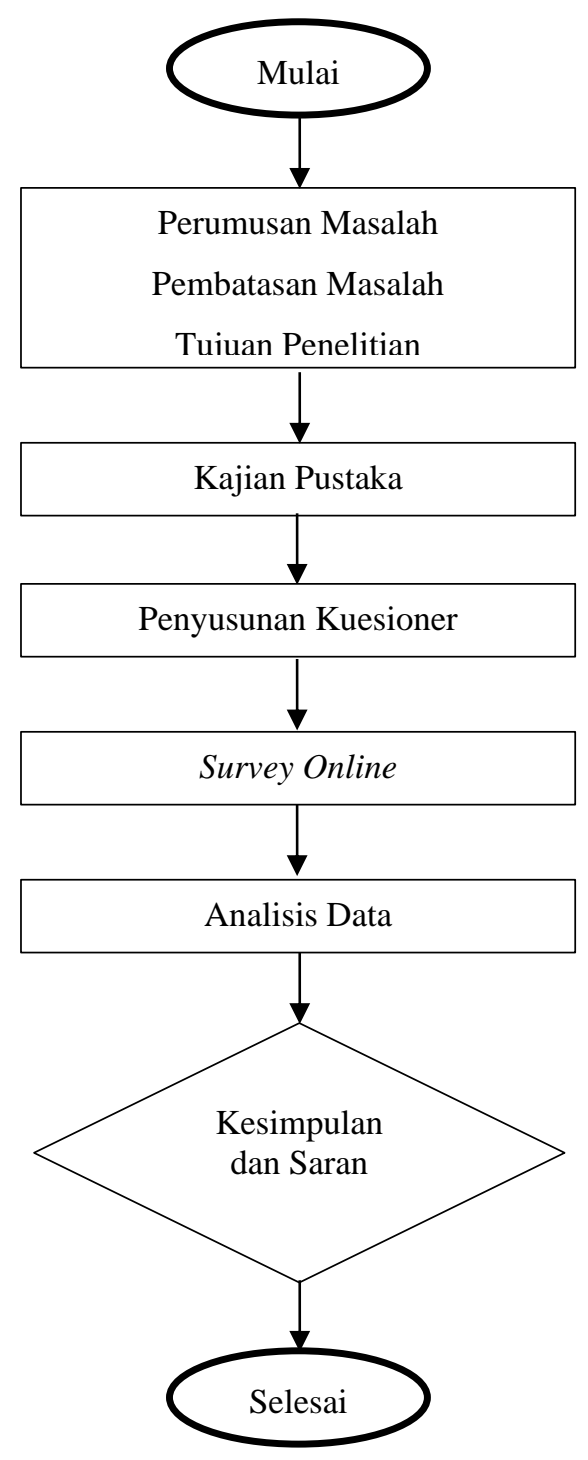

Gambar 1. Diagram alir tahapan penelitian

\section{Jenis penelitian}

Penelitian yang dilakukan dikhususkan pada jalur lintas Bogor - Jakarta Kota. Data didapatkan melalui survey online, disebarluaskan dengan link google form. Survey ini ditujukan pada konsumen sebagai penumpang KRL Commuter Line mengenai perilaku penumpang dan operator dalam menerapkan protokol kesehatan dan kebijakan lain yang berlaku di masa pandemi Covid-19. Survey ini dilakukan pada jam kapan pun selama masih dalam jalur lintas Bogor - Jakarta Kota.

\section{Responden atau objek studi}

Responden yang dijadikan objek studi dalam analisis penulis ialah konsumen sebagai penumpang KRL Commuter Line yang menggunakan jalur lintas Bogor - Jakarta Kota. Semua responden yang akan diwawancara dengan survey online diharapkan bisa memberikan jawaban yang jujur sesuai dengan kenyataan yang ada di lapangan, sehingga hasil penelitian ini memiliki validitas yang tinggi dan dapat dipertanggungjawabkan keaslian datanya. Untuk para responden yang merupakan penumpang dibedakan dari segi jenis kelamin, usia, pendapatan per bulan, pekerjaan yang dilakukan, frekuensi penggunaan KRL Commuter Line, persepsi terhadap penerapan protokol kesehatan ataupun kebijakan lainnya yang diterapkan oleh operator moda jasa transportasi PT. KCI menurut para penumpang, dan pengaruhnya terhadap pola perjalanan penumpang. 


\section{Metode pengumpulan data}

Dalam mengumpulkan data, metode yang digunakan adalah menggunakan kuesioner. Kuesioner merupakan sejumlah pertanyaan atau pernyataan tertulis tentang data faktual atau opini yang berkaitan dengan diri responden, yang dianggap fakta atau kebenaran yang diketahui dan perlu dijawab oleh responden (Sutoyo). Kuesioner disebarluaskan dengan cara online (tidak dilakukan secara langsung) untuk mengetahui dan mengidentifikasi bagaimana pendapat dari sudut pandang penumpang terhadap dirinya sendiri dan operator petugas yang bertugas di area stasiun atau di rangkaian KRL. Hal lain yang dituliskan dan dilakukan analisis ialah persepsi penumpang mengenai penerapan kebijakan protokol kesehatan yang seharusnya dilakukan oleh operator petugas PT. KCI. Wawancara ini diharapkan dapat dijawab oleh penumpang yang terpercaya, guna mendapatkan hasil data penelitian yang valid.

\section{Metode analisis data}

Dari desain penelitian yang telah dirancang melalui kuesioner, maka didapatkan persepsi perilaku masing-masing dari penumpang khususnya juga dari sisi pihak PT. Kereta Commuter Indonesia. Masing-masing paparan persepsi yang didapat dilakukan analisis melalui penumpang terhadap kebijakan-kebijakan dan peraturan yang sudah diberlakukan mengenai protokol kesehatan, apakah sudah sesuai dengan praktik di lapanga. Melalui persepsi pendapat yang sudah dipaparkan dari penerapan kebijakan dari penumpang itu sendiri maupun petugas yang bertugas dapat dibuat penilaian secara subjektif seberapa terealisasi kebijakan-kebijakan yang diberlakukan dari badan WHO dan di adaptasi kembali sesuai di negara Indonesia oleh Menhub dan Kemenkes. Setelah melakukan analisis terhadap persepsi pendapat dengan faktual yang terjadi melalui Analisis Normatif tersebut, dengan Analisis Deksriptif dibuat kesimpulan dengan gambaran berdasarkan paparan dari sudut pandang responden mengenai kebijakan yang diberlakukan ini. Dari datadata tiap pendapat persepsi dan saran serta masukan yang telah dipaparkan dilakukan analisis kembali agar didapatkan hasil yang ideal bagi semua pihak dan di evaluasi. Hasil evaluasi yang didapatkan akan mempresentasikan hasil publik terhadap kebijakan yang berlaku khususnya pada KRL Commuter Line.

\section{HASIL DAN PEMBAHASAN}

\section{Data responden}

Data yang didapatkan secara Daring (Dalam Jaringan) atau survey online menggunakan Google Form direncanakan untuk 100 responden, namun hasil responden yang didapat ada sebanyak 106 responden dengan hasil yang beragam.

Pada pembagian pertama yaitu mengenai tingkat kewaspadaan dari penumpang KRL Commuter Line di tabel 1.

Tabel 1. Tingkat kewaspadaan penumpang KRL Commuter Line

\begin{tabular}{|c|c|c|}
\hline Kriteria & Iya & Tidak \\
\hline \multicolumn{3}{|l|}{ Menuju Stasiun Keberangkatan } \\
\hline $\begin{array}{l}\text { Melakukan Sterilisasi Pada Area Tempat Duduk Dari } \\
\text { Angkutan Yang Ditumpangi }\end{array}$ & 48,1 & 51,9 \\
\hline $\begin{array}{l}\text { Pematuhan Terhadap Protokol Kesehatan Saat Berada Pada } \\
\text { Angkutan Yang Ditumpangi }\end{array}$ & 99,1 & 0,9 \\
\hline $\begin{array}{l}\text { Sterilisasi Pada Diri Sendiri Setelah Selesai Menaiki Angkutan } \\
\text { Yang Ditumpangi }\end{array}$ & 83 & 17 \\
\hline \multicolumn{3}{|l|}{ Saat di Stasiun Keberangkatan } \\
\hline Pemakaian Masker dan Peralatan Pelindung Lain & 100 & 0 \\
\hline Melakukan Aktivitas Jaga Jarak & 97,2 & 2,8 \\
\hline $\begin{array}{l}\text { Melakukan Tindakan Sterilisasi Diri Setelah Aktivitas } \\
\text { Pembelian Tiket atau Memasuki Gate }\end{array}$ & 86,8 & 13,2 \\
\hline
\end{tabular}


Tabel 1. Tingkat kewaspadaan penumpang KRL Commuter Line (Lanjutan)

\begin{tabular}{lcc}
\hline \multicolumn{1}{c}{ Kriteria } & Iya & Tidak \\
\hline Perjalanan Saat di Dalam Kereta & & \\
Pematuhan Terhadap Protokol Kesehatan Saat di Dalam Kereta & 98,1 & 1,9 \\
Pematuhan Terhadap Pembatasan Tempat Duduk Yang & 97,2 & 2,8 \\
Disediakan di Dalam Kereta & \\
Tindakan Menjaga Jarak Saat Mengantri Masuk ke Dalam & 98,1 \\
Kereta dan di Dalam Kereta & \\
Penggunaan Telefon Genggam Selama Perjalanan & 80,2 & 19,8 \\
Saat di Stasiun Tujuan & \\
Pematuhan Protokol Kesehaan dan Kebijakan Lainnya Saat di & 99,1 & \\
Stasiun Tujuan & & 0,9 \\
Melakukan Tindakan Sterilisasi Diri Setelah Turun Dari Kereta & 78,3 & 21,7 \\
\hline Rata-rata & 88,8 & 11,2 \\
\hline
\end{tabular}

Pada pembagian kedua merupakan tingkat realisasi fasilitas yang dilakukan oleh operator KRL Commuter Line yang disajikan pada tabel 2.

Tabel 2. Tingkat realisasi fasilitas oleh operator KRL Commuter Line

\begin{tabular}{|c|c|c|}
\hline Kriteria & Iya & Tidak \\
\hline \multicolumn{3}{|l|}{ Saat di Stasiun Keberangkatan dan Stasiun Tujuan } \\
\hline $\begin{array}{l}\text { Ketersediaan Fasilitas Mencuci Tangan di Stasiun } \\
\text { Keberangkatan }\end{array}$ & 97,2 & 2,8 \\
\hline Fungsi Fasilitas Mencuci Tangan di Stasiun Keberangkatan & 92,5 & 7,5 \\
\hline $\begin{array}{l}\text { Ketersediaan Sabun Yang Mencukupi Pada Fasilitas Cuci } \\
\text { Tangan di Stasiun Keberangkatan }\end{array}$ & 77,4 & 22,6 \\
\hline Ketersediaan Hand Sanitizer di Stasiun Keberangkatan & 87,7 & 12,3 \\
\hline $\begin{array}{l}\text { Ketersediaan Hand Sanitizer Yang Mencukupi di Stasiun } \\
\text { Keberangkatan }\end{array}$ & 72,6 & 27,4 \\
\hline $\begin{array}{l}\text { Himbauan Yang Didapat Untuk Tetap Melaksanakan Protokol } \\
\text { Kesehatan Dalam Mengatasi Bahaya Covid-19 di Stasiun } \\
\text { Keberangkatan }\end{array}$ & 96,2 & 3,8 \\
\hline $\begin{array}{l}\text { Ketersediaan Fasilitas Mencuci Tangan dan Hand Sanitizer di } \\
\text { Stasiun Tujuan }\end{array}$ & 96,2 & 3,8 \\
\hline
\end{tabular}


Tabel 2. Tingkat realisasi fasilitas oleh operator KRL Commuter Line (Lanjutan)

\begin{tabular}{|c|c|c|}
\hline Kriteria & Iya & Tidak \\
\hline \multicolumn{3}{|l|}{ Saat di Dalam Rangkaian KRL } \\
\hline $\begin{array}{l}\text { Pembatasan Tempat Duduk Yang Sudah Diatur Sesuai Batas } \\
\text { Kapasitas Yang Diberlakukan Pihak PT. KCI Menurut } \\
\text { Kebijakan Menhub dan Kemenkes }\end{array}$ & 96,2 & 3,8 \\
\hline $\begin{array}{l}\text { Penyediaan Fasilitas Hand Sanitizer Pada Kereta Yang } \\
\text { Digunakan }\end{array}$ & 50,9 & 49,1 \\
\hline $\begin{array}{l}\text { Himbauan Yang Didapat Untuk Tetap Melaksanakan Protokol } \\
\text { Kesehatan Dalam Mengatasi Bahaya Covid-19 di Dalam Kereta }\end{array}$ & 93,4 & 6,6 \\
\hline Adanya Tindakan Sterilisasi Pada Kereta Yang Ditumpangi & 69,8 & 30,2 \\
\hline Rata-rata & 84,6 & 15,4 \\
\hline
\end{tabular}

Pada pembagian ketiga merupakan tingkat realisasi pengaturan yang ditegakkan oleh petugas KRL Commuter Line yang disajikan pada tabel 3.

Tabel 3. Tingkat realisasi pengaturan oleh petugas KRL Commuter Line

\begin{tabular}{lcc}
\hline \multicolumn{1}{c}{ Kriteria } & Iya & Tidak \\
\hline Pemeriksaan Suhu Tubuh Oleh Petugas & 95,3 & 4,7 \\
Penganjuran Penumpang Untuk Saling Menjaga Jarak Oleh & 83 & 17 \\
Petugas & & 15,1 \\
$\begin{array}{l}\text { Peneguran Penumpang Yang Melanggar Protokol Kesehatan } \\
\text { Oleh Petugas }\end{array}$ & 84,9 & \\
$\begin{array}{l}\text { Pengarahan Pergerakan Penumpang Pada Area Stasiun Yang } \\
\text { Terjadi Penumpukan Penumpang Oleh Petugas }\end{array}$ & 72,6 & 17 \\
$\begin{array}{l}\text { Pengarahan Penumpang Oleh Petugas Untuk Duduk atau } \\
\text { Berdiri Sesuai Dengan Tempat Yang Disediakan }\end{array}$ & 83 & 16,2 \\
\hline \multicolumn{1}{c}{ Rata-rata } \\
\end{tabular}

\section{Analisis pola perjalanan}

Dalam analisis pola perjalanan penumpang KRL Commuter Line, penelitian ini melakukan pembatasan cakupan aspek perubahan pada pola perjalanan hanya berdasarkan pada kebijakan - kebijakan yang ditetapakan oleh pemerintah pusat khususnya yang berpengaruh baik langsung maupun tidak langsung. Pengaruh kebijakan tersebut dapat dilihat pada pembatasan yang diterapkan pada pembatasan terhadap kapasitas angkut dari rangkaian KRL, pembatasan jadwal jam operasional KRL, pembatasan usia penumpang yang menaiki KRL, serta kebijakan mengenai Work From Home (WFH). Kebijakan Work From Home sendiri dapat berbentuk pembatasan hari kerja pada para pekerja dalam seminggu, pembatasan jam kerja dalam satu hari, serta pembatasan jumlah pekerja di tempat kerja dalam satu waktu.

Analisis pola perjalanan ditinjau berdasarkan aspek keamanan dan kenyamanan penggunaan KRL Commuter Line dan juga kebijakan pemerintah yang dianjurkan khususnya mengenai Work From Home.

\section{Keamanan dan kenyamanan}

Melalui paparan sudut pandang penumpang KRL Commuter Line merasa sudah cukup aman dan nyaman untuk melakukan perjalanan transportasi dengan KRL Commuter Line khususnya pada lintas Bogor - Jakarta Kota, namun tidak dapat dihindarkan ada beberapa responden yang menyatakan tetap merasa kurang bahkan tidak aman dan 
nyaman dalam melakukan perjalanan transportasi. Berdasarkan tanggapan responden didapat $\geq 80 \%$ penumpang KRL Commuter Line merasa dengan adanya kebijakan - kebijakan yang ada pada masa pandemi ini berpengaruh terhadap perjalanan transportasinya, beberapa di antaranya menyebutkan bahwa jadi lebih waspada dan hati-hati lagi, serta melakukan banyak persiapan untuk melakukan suatu perjalanan.

Jika dilihat dari sudut pandang penumpang KRL Commuter Line selaku responden pada penelitian ini, dengan tingginya tingkat keamanan dan kenyamanan yang dirasakan, dapat dikatakan operator yaitu PT. Kereta Commuter Indonesia sudah cukup baik dalam menerapkan protokol kesehatan dan menyediakan fasilitas-fasilitas yang dianjurkan apabila ingin menggunakan transportasi umum KRL Commuter Line dengan mengaplikasikan sesuai dari kebijakan Kemenkes dan Permenhub yang diadaptasi dari World Health Organization (WHO). Sehingga bisa didapatkan penumpang memiliki rasa aman dan nyaman ketika menggunakan KRL Commuter Line pada jalur lintas Bogor - Jakarta Kota khususnya pada masa pandemi.

\section{Kebijakan pemerintahan}

Yang menjadi fokus tinjauan pada analisis bagian ini adalah dari sisi protokol, dimana pengaruh itu dapat dilihat dari apa yang telah dirasakan setelah adanya kebijakan ini, dan juga dari sisi kebijakan soal anjuran pemerintah mengenai Work From Home (WFH), yang dimana berdasarkan hasil persepsi responden merupakan keinginan personal dari responden itu sendiri.

Dengan berpengaruhnya kebijakan - kebijakan yang ada pada masa pandemi ini terhadap perjalanan transportasi penumpang KRL Commuter Line, didapat sebanyak 65 responden memilih untuk melakukan pembatasan terhadap kegiatan luar, 18 responden memilih tetap melakukan kegiatan luar dengan merubah waktu keberangkatan yang digunakan dari yang biasanya, dan sebanyak 6 responden memilih untuk membatalkan segala kegiatan luar.

Dari sudut pandang penumpang KRL Commuter Line selaku responden pada penelitian ini, dapat dikatakan PT. Kereta Commuter Indonesia sudah cukup baik menerapkan protokol kesehatan yang dianjurkan apabila ingin menggunakan transportasi umum KRL Commuter Line dengan mengaplikasikan sesuai dari kebijakan Kemenkes dan Permenhub yang diadaptasi dari World Health Organization (WHO). Dari sudut pandang penumpang KRL Commuter Line juga menyatakan penumpang yang menggunakan KRL Commuter Line dinilai sudah sadar terhadap kesehatannya masing - masing dan juga lingkungan sekitarnya, dengan taat mengaplikasikan protokol kesehatan yang dianjurkan untuk melakukan perjalanan transportasi.

\section{KESIMPULAN DAN SARAN}

\section{Kesimpulan}

Berdasarkan dari hasil kajian studi penelitian, maka dapat disimpulkan sebagai berikut:

1. Pada tingkat kewaspadaan responden pengguna sebagai penumpang KRL Commuter Line lintas Bogor Jakarta Kota didapat sebagai berikut:

a. Untuk persiapan dari rumah, hal-hal yang sering kali disiapkan oleh pengguna KRL Commuter Line pada masa pandemi Covid-19 ialah dengan menggunakan masker dan membawa atau menyiapkan hand sanitizer sendiri.

b. Saat perjalanan menuju stasiun keberangkatan, responden umumnya tidak melakukan sterilisasi pada angkutan yang ditumpanginya, namun setelah selesai menumpang responden melakukan tindakan sterilisasi diri.

c. Hampir seluruh responden mematuhi protokol kesehatan di angkutan yang ditumpanginya untuk menuju stasiun keberangkatan

d. Saat di stasiun keberangkatan, perjalanan dengan Commuter Line, dan saat di stasiun tujuan, pengguna KRL Commuter Line rata-rata mematuhi protokol kesehatan yang diperlakukan dalam melakukanj perjalanan diri lainnya, melakukan aktivitas jaga jarak, dan melakukan tindakan pembersihan diri (sterilisasi) baik mencuci tangan dengan sabun ataupun hand sanitizer.

e. Penumpang KRL Commuter Line sebanyak 67,9\% melakukan aktivitas berupa bermain game/mendengarkan musik di handphone pada saat menunggu di dalam area stasiun.

f. Ada sebanyak $80,2 \%$ penumpang KRL Commuter Line menggunakan telefon genggam selama perjalanannya dengan KRL Commuter Line.

g. Mayoritas penumpang KRL Commuter Line juga menyatakan bahwa 88,8\% rata-rata penumpang sudah awas dan waspada untuk menerapkan protokol kesehatan pada dirinya sesuai dengan arahan Menhub dan Kemenkes yang diadaptasi dari regulasi World Health Organization (WHO).

h. Mayoritas penumpang KRL Commuter Line menyatakan bahwa 84,6\% rata-rata penerapan kebijakankebijakan protokol kesehatan dalam transportasi yang diaplikasikan oleh PT. Kereta Commuter Indonesia 
khususnya mengenai fasilitas yang diharikan sudah terealisasikan sesuai dengan arahan Menhub dan Kemenkes yang diadaptasi dari regulasi World Health Organization (WHO).

i. Mayoritas penumpang KRL Commuter Line juga menyatakan bahwa 83,8\% rata-rata petugasnya sudah merealisasikan pengaturan yang semestinya dilakukan dan ditegakkan sesuai dengan arahan Menhub dan Kemenkes yang diadaptasi dari regulasi World Health Organization (WHO).

j. Ada sebanyak 69,8\% penumpang KRL Commuter Line mengetahui adanya tindakan sterilisasi dan pembersihan lainnya pada rangkaian kereta yang dinaiki.

2. Pada tingkat keamanan, kenyamanan, dan pengaruh terhadap perjalanan transportasi penumpang KRL Commuter Line lintas Bogor - Jakarta Kota didapat sebagai berikut:

a. Penumpang KRL Commuter Line didominasi oleh pernyataan setuju terkait rasa aman dan terlindungi dari rumah sampai stasiun keberangkatan, saat di stasiun keberangkatan, saat perjalanan di kereta, saat tiba di stasiun tujuan.

b. Dominan penumpang KRL Commuter Line menjawab bahwa akan segera melapor secara mandiri ataupun menunggu panggilan dari pihak PT. KCI apabila seandainya terdapat laporan hasil positif kasus reaktif Covid-19 pada jadwal keberangkatannya, guna untuk melakukan tracing (penelurusan) yang dilakukan oleh PT. Kereta Commuter Indonesia.

c. Kebanyakan penumpang KRL Commuter Line menyatakan dengan adanya kebijakan-kebijakan dan regulasi yang berlaku pada masa pandemi khususnya terhadap perjalanan transportasinya jadi berpengaruh.

3. Pengaruh yang dirasakan pada umumnya adalah jadi lebih banyak hal yang dilakukan untuk mempersiapkan suatu perjalanan, juga kebanyakan berimbas untuk membatasi kegiatannya di luar.

4. Mengenai anjuran pemerintah soal Work From Home, keinginan penumpang KRL Commuter Line di dominasi oleh pernyataan setuju.

\section{Saran pemanfaatan penelitian}

Berdasarkan penelitian yang sudah dilakukan didapatkan saran terhadap pemanfaatan penelitian yang dapat disampaikan, yakni:

1. Dapat diketahui bahwa pelayanan dari pihak operator PT. Kereta Commuter Indonesia khususunya pada masa pandemi Covid-19 ini sudah baik, karena seluruh aturan regulasi yang berlaku pada aktivitas bertransportasi direalisasikan cukuo merata khususnya pada jalur lintas Bogor - Jakarta Kota. harapannya ialah agar pihak operator dapat tetap mempertahankan pelayanannya, juga ditingkatkan lagi khususnya pada beberapa faktor yang masih berada dibawah nilai rata-rata perlu untuk di evaluasi kembali berdasarkan paparan dair responden penumpang KRL Commuter Line.

2. Penelitian ini dilakukan pada saat Pandemi Coronavirus masih berlangsung di Indonesia, karena adanya keterbatasan tersebut hasil data kuesioner merupakan hasil dari Survey Online secara Daring (Dalam Jaringan) sehingga tidak dapat maksimal dan tingkat validasinya cukup kurang, serta kurang diaksesnya link survey ini yang menjadi salah satu permasalahan kurang terwakilkannya data dari pengisian kuesioner. Sangat disarankan untuk yang melanjuti penelitian ini untuk dilengkapi dengan kuesioner berbasis offline (face to face) pada saat kondisi yang sudang memungkinkan, sehingga data dapat lebih valid dan terjangkau lebih luas.

\section{DAFTAR PUSTAKA}

Levinson, H.S. “Urban Travel Characteristic Bearwaid.” Baerwald, J.E. (ed.). Transportation and Traffic Engineering Handbook. New Jersey: Prentice Hall, 1976.

PT. Kereta Commuter Indonesia. Panduan Tatanan Normal Baru Bagi Commuters. Jakarta, 2020.

Satuan Tugas Penanganan COVID-19. "Kemenhub Terbitkan Aturan Pengendalian Transportasi Menuju Masyarakat Aman COVID-19 dan Produktif." 9 Juni 2020. https://covid19.go.id/p/berita/kemenhub-terbitkan-aturanpengendalian-transportas-menuju-masyarakat-aman-covid-19-dan-produktif. Diakses 19 September 2020

Satuan Tugas Penanganan COVID-19. "Pedoman Pencegahan dan Pengendalian CORONAVIRUS DISEASE (COVID-19) Revisi ke-5.” 28 Juli 2020. https://covid19.go.id/p/protokol. Diakses 21 September 2020.

Sutoyo, A. Pemahaman Individu, Observasi, Checklist Interview, Kuisioner dan Sosiometri. Yogyakarta: Pustaka Belajar, 2009.

World Health Organization. "WHO Coronavirus Disease (COVID-19) Dashboard.” 3 Januari 2020. https://covid19.who.int/. Diakses 19 September 2020. 

